\title{
"Our Land Is Shrinking": Concerns and Misconceptions Impeding Uptake of Climate Risk Mitigation Policies in Bududa and Butalejja Districts in Eastern Uganda
}

\author{
Roy William Mayega ${ }^{1,2, *}$, Nathan Tumuhamye ${ }^{1}$, Grace Mongo Bua ${ }^{1}$, Julius Ssentongo ${ }^{1}$, \\ Harriet Adong ${ }^{1}$, Kathleen Giles ${ }^{4}$, Stella Neema ${ }^{6}$, Christine Muhumuza ${ }^{1,2}$, William Bazeyo ${ }^{1,3}$, \\ James Fishkin ${ }^{4}$, Lynn Atuyambe ${ }^{5}$ \\ ${ }^{1}$ ResilientAfrica Network, School of Public Health, Makerere University, Kampala, Uganda \\ ${ }^{2}$ Department of Epidemiology and Biostatistics, School of Public Health, Makerere University, Kampala, Uganda \\ ${ }^{3}$ Department of Disease Control and Environmental Health, School of Public Health, Makerere University, Kampala, Uganda \\ ${ }^{4}$ Center for Deliberative Democracy/HSTAR, Stanford University, Stanford, California, USA \\ ${ }^{5}$ Department of Community Health and Behavioural Sciences, School of Public Health, Makerere University, Kampala, Uganda \\ ${ }^{6}$ College of Humanities and Social Sciences, Makerere University, Kampala, Uganda
}

Email address:

wromay2000@yahoo.co.uk (R. W. Mayega)

${ }^{*}$ Corresponding author

To cite this article:

Roy William Mayega, Nathan Tumuhamye, Grace Mongo Bua, Julius Ssentongo, Harriet Adong, Kathleen Giles, Stella Neema, Christine Muhumuza, William Bazeyo, James Fishkin, Lynn Atuyambe. "Our Land Is Shrinking": Concerns and Misconceptions Impeding Uptake of Climate Risk Mitigation Policies in Bududa and Butalejja Districts in Eastern Uganda. Science Journal of Public Health.

Vol. 9, No. 4, 2021, pp. 109-120. doi: 10.11648/j.sjph.20210904.11

Received: April 30, 2021; Accepted: May 31, 2021; Published: June 9, 2021

\begin{abstract}
Background: Globally, the incidence of disasters is rising. Uganda is one of several countries experiencing an upturn in adverse climate events. Although Uganda's government has implemented several strategies to mitigate land-use and population pressure-related climate adversity in high-risk zones, communities have not responded to them sufficiently, implying a resilience gap. The objective of this study was to describe the concerns and misconceptions impeding community uptake of climate risk mitigation policies in a rural area in Eastern Uganda. Methods: The study was conducted in Butalejja and Bududa districts in the Mt. Elgon region of Eastern Uganda that is prone to recurrent land-slides and floods. The design was a qualitative study, consisting of 15 small group discussions per district, nested within a Deliberative Poll@. Key government of Uganda policy options on sustainable settlement and family planning were presented to participants who then discussed them with the guidance of a moderator. Results: Not only were participants distrustful of how the land from which they are evacuated would be managed, but they also resented being resettled in unfamiliar places with substantially different topography, low soil fertility, and at a great distance from their ancestral sites and social networks. A latent theme from the data was the pervasive expectation by communities to be assisted by government in all areas of their livelihood needs. Key barriers to Family Planning included lack of safety guarantees, helplessness in the event of a side effect, failure by communities to link family size to resource constraints, and feelings of entitlement to assistance among people with large families. The misconceptions were fueled by a large information asymmetry between the community members and the policy makers. Conclusion: Lasting solutions to climate risk in rural communities will require continuous information-driven dialogue between community members and implementers to address major misconceptions and information asymmetries regarding risk mitigation policies.
\end{abstract}

Keywords: Policy, Deliberative Polling, Climate Risk-Mitigation, Disaster, Land Use, Family Planning 


\section{Background}

Globally, the incidence of natural and man-made disasters is on the rise [1]. This is attributed to increased climate variability due to climate change, increasing population pressure on natural resources and habitats [2], conflict and complex emergencies, and rapid urbanization amidst nonresilient infrastructure [3]. Billions of dollars have been spent by humanitarian and development agencies to mitigate these events. Although these investments have saved lives, they would realize even greater impact on recurrent losses if they built the resilience of vulnerable communities [3].

Uganda is one of several countries experiencing a rise in adverse climate events [4]. Although these incidents are attributable to climate variability, there is evidence of climate change as drier regions of the country are becoming drier, and rainy regions rainier, with changing seasons [5]. Recent adverse events have occurred in the West-Nile region (recurrent epidemics), Northern Uganda (epidemics and floods), the Albertine region (epidemics and floods), Karamoja and the 'Cattle corridor' (drought and famine), Central and Western regions (soil exhaustion, banana and coffee wilt) and the South Western Region (child malnutrition). Their recurrence with similar effects represents a resilience gap. Resilience, as defined by the ResilientAfrica Network (RAN), is the capacity of people and systems to mitigate, adapt to, recover and learn from shocks and stresses in a manner that reduces their vulnerability and increases well-being [3].

The Elgon Region in Uganda is one of the most prone to adverse climate events, affected by recurrent landslides in the mountainous districts (e.g. Bududa, Bulambuli and Sironko), and recurrent floods and epidemics of sanitation related diseases like cholera and dysentery in the low-lying districts (e.g. Manafwa, Butalejja and Busia). Vulnerability to recurrent adverse climate events in this region is closely associated with livelihoods, population size and land-use. Eighty percent of the population relies heavily on climate-fed agriculture, which is land intensive, but increasingly, land is becoming scarce due to population pressure. At a total fertility rate of 5.6 and an annual growth rate of $3 \%$, Uganda's annual population growth rate is among the highest globally [6]. Currently home to over 2 million people, and with a population density of 950 people per square kilometer (compared to the national average of 173), the Mt. Elgon region has one of the highest population densities in Africa [7]. The high population density coupled with the rapid population growth in this region has driven communities to deplete natural resources and encroach on high-risk areas (higher in the mountains and lower in the low-lying areas), which has in turn increased the probability of landslides and floods. Settlement in hard-to-reach areas has also constrained the community's access to education, health, sanitation and housing. The difficult terrain drives children to delay their education, which fuels early marriages, especially among girls.

Uganda's government has implemented three types of strategies to mitigate land-use related climate risk and population pressure in such regions: (a) Resettlement of the most-at-risk populations; (b) Promotion of rational use of land within high risk zones; and, (c) Promotion of Family Planning. Within these broad approaches are a range of suboptions including: (1) Re-zoning high risk areas for no settlement, resulting in (2) Negotiated resettlement in other areas away from the most affected areas, or (3) Forced resettlement; (4) Creation of semi-urban areas in lower risk zones within the affected area, with controlled farming in the moderate risk areas; (5) Temporary relocation to stay with relatives at onset of heavy rains; (6) Implementing locally appropriate early warning for imminent floods and landslides; (7) Regular desilting of drainage channels and small river beds by either government or the communities;(8) Strengthening of local disaster management committees; (9) Mass health education on Family Planning; (10) Provision of free Family Planning services at all primary care facilities; (11) Promotion of post-partum contraception. Government has also put in place measures to increase access to basic education, both at primary and secondary levels, and to promote livelihoods diversification.

These measures have, however, not been sufficient to prevent communities from encroaching on high risk zones, to slow the rapid population growth, or to reduce the population's dependence on subsistence agriculture. The ResilientAfrica Network (RAN) hypothesized that the failure of the communities to take up climate risk related policies is in part linked to information asymmetries between them and the policy makers, which impairs their considered judgments in adoption behaviors. This is because communities are not adequately involved in evaluating different policy options before their roll-out. The broad objective of the Deliberative Polls (DP) conducted in Bududa and Butalejja was to assess whether or not opinions regarding climate risk mitigation policies can change when the population is deeply involved in discussions of those policies. The specific objective of this sub-analysis of the Deliberative Polls was to understand the community concerns and information gaps that push them to shun climate risk related policies. Deliberative Polling ${ }^{\circledR}$ is a registered trade mark of James S. Fishkin of the Stanford Center for Deliberative Democracy which ensures that such polls are conducted with acceptable quality standards.

\section{Methods}

\section{Study site and setting}

This paper focuses on the qualitative analysis conducted on the data collected from the small group discussions during the deliberation workshops. The quantitative analysis is published elsewhere [8]. The study was conducted in Bududa and Butalejja Districts located in the Mt. Elgon Region, Eastern Uganda, each with a population of about 200,000 . Bududa is mountainous with $80 \%$ of the villages located on steep slopes. The main economic activity is subsistence agriculture. The fertile slopes are ideal for growing Arabica coffee. The district has had recurrent land-slides associated with the peak of the 
rainy seasons. The frequency of landslides seems to have intensified over the last decade. In 2010, over 300 people died in a major landslide whose epicenter was Bulucheke subcounty [9]. A visible crack crosses through 14 sub-counties in 4 districts in the region. Butalejja is mainly a low-lying flat district adjoining Bududa. The main economic activity there is paddy rice growing, which covers $70 \%$ of the district. The rice-growing flood plains are serviced by River Manafwa which runs from the higher districts of Bududa and Manafwa, carrying and depositing silt into the lower marshlands. The government has established a dam and drainage system to control the flow of flood waters to the rice farms. Despite being a controlled flood plain, the district has been hit by recurrent major floods attributed to heavy rains and untended silting at the confluence of the two main river tributaries. Both districts have faced recurrent outbreaks of cholera and other sanitation related diseases also associated with the rainy season.

Study design

An innovative approach to community consultation known as Deliberative Polling ${ }^{\circledR}$ was used. This application compares community opinions before and after a moderated deliberation process involving a random, representative sample of the population. Applied for the first time in Africa, this approach involves six steps, including: (1) a desk review and stakeholder consultations to document existing policies on the issues of interest, their alternatives and their pros and cons, (2) developing briefing materials and a structured opinion assessment questionnaire, (3) identification and training of data collectors and moderators, (4) selection of a random, representative sample of the population and conducting a baseline opinion poll regarding the policy options, (5) convening the sampled individuals for moderated small group discussions on the topics of the deliberative poll, followed by larger plenary sessions where the sample has an opportunity to ask questions to experts; the deliberative processes last approximately two days (6) a post deliberation poll to assess whether participants' opinions on policy options changed as a result of the deliberation. The results of the final questionnaire give the considered opinions of the participants after they have had an opportunity to deliberate on the issues. The detailed methodology for this study has already been published elsewhere [8].

Adaptation of Deliberative Polling ${ }^{\circledR}$ to local settings

In a low-income country (LIC) like Uganda with low literacy rates $(70.2 \%)$ [10], the design of the DP must put into consideration the need to adequately facilitate the discussions among ordinary citizens who vary widely in education level and technical experience, so that they can usefully weigh the competing arguments and policy options at issue. The design therefore ensured that all briefing materials for the policy discussions were translated into video recordings using the respective local languages, which allowed the non-literate participants to comprehend them and participate fully in the deliberation. In order not to bias participants' opinions, the briefing materials were balanced, presenting both the pros and cons of the different policy options. The session moderators were also appropriately trained to be able to facilitate balanced discussions by bringing out competing arguments from the briefing materials and also ensuring that minority opinions were respected. [8].

\section{Data collection}

Desk reviews and stakeholder consultations: A review of existing policy and program documents was conducted to determine pertinent policies and their alternatives regarding mitigation of the adverse climate events in the region. We reviewed current policy reports from both government and development agencies as well as articles from peer reviewed journals. Two 2-day consultative workshops involving policy makers and disaster management practitioners were conducted to further validate the emergent policies and their alternatives. The first workshop comprised 16 workshop participants from Makerere University involved in climate risk research, and from Stanford University's Center for Deliberative Democracy. Participants represented multi-disciplinary fields such as public health, social sciences, finance and administration, communications, political science, engineering and geography.

The second workshop had more participants and more fields represented. In addition to the Academic sector and fields indicated above in workshop 1, workshop 2 included: Government ministries involved in disaster preparedness, environmental protection, and climate risk mitigation; Development agencies involved in resilience and climate change mitigation such as UNDP, Uganda Red Cross Society, World Vision, USAID; District local governments and community representatives.

Thirty-six (36) policy issues and options emerged from this analysis, clustered under three themes: (1) Re-settlement management, (2) land-use management and (3) managing population pressure. (See Table A1 (Appendix).

Developing the intervention and opinion assessment tools: The policy issues identified from the desk review and stakeholder consultations were adapted into an opinion survey questionnaire. For each of the 36 policy options, the questionnaire was designed to rate the respondents' support for the option on a 10-point ordinal attitude scale ranging from $0=$ completely unacceptable to $10=$ completely acceptable. A set of briefing materials describing the 36 policy options and evaluating their pros and cons was developed. Given the low population literacy, a fifteenminute video version of the briefing materials was produced by a student team from the Mass Communication Department at Makerere University.

Identification and training of the data collection team: Sixty research assistants were identified, 30 from each district. The research assistants were residents of the Mt. Elgon region, with the minimum qualification of a diploma and experience in household surveys. They underwent a twoday training. The training also incorporated a field session to pretest the tools in two non-study sub-counties in the region (Wesswa in Manafwa district and Kachonga in Butalejja district). The reason for choosing these sub-counties was that they shared similar population characteristics and challenges with the study sub-counties. 30 moderators were also identified to facilitate the small-group discussions. These had a minimum of a Bachelors' degree and experience in survey 
administration, including leading data collection teams and moderating group discussions.

Sampling and baseline opinion survey: The DP participants were selected with the help of a three-stage sampling process. In the first stage, 7 sub counties from Bududa district were randomly selected: three from high risk, two from moderate risk, and one from low risk areas. Selection of the sub counties was guided by the Bududa District Disaster Management Plan 2013, which stipulates ten high risk, five medium risk and one low risk sub-counties. For Butalejja, there is was no risk assessment report available, but from discussions with the district officials, three sub counties were categorized as high risk, five sub counties as moderate risk and four sub counties as low risk. Using a ratio of 1: 1: 1 a total of six sub counties two high risk, two moderate risk, and two low risk were randomly selected. In the second selection stage, three parishes from each sub county were selected using simple random sampling and the sample size for the district was then allocated to the parishes (21 in Bududa and 18 in Butalejja) proportionate to their population sizes. In the third and final stage, participants aged 18-75 years were randomly selected from the parishes. A list of the households, and their adult occupants in each of the selected parishes was compiled by community scouts identified in the respective parishes. Within each sampled household, one participant aged 18 years and above was randomly selected from the household members. As part of the consent process, participants were asked about their availability to participate in the deliberative poll. Consenting participants then underwent the baseline opinion survey on the key policy options described earlier. Thereafter they received an invitation to participate in the deliberation workshop, signed by the Chief Administrative Officer (CAO), who is the top bureaucrat in the district. Sampled participants were then followed-up by local community mobilizers to remind them to attend the deliberation workshop.

Two-day deliberation workshops on the policy issues: Participants gathered at a central venue in each of the target districts for the deliberation workshop. The deliberation process, the main methodology from which the findings of this manuscript are extracted, lasted two days. The aim of deliberation was to ensure that participants became adequately informed on the policy issues and shared their rationale for supporting or opposing the proposed options. Carefully balanced briefing materials were presented to the participants by the moderators. A video version of the briefing materials was also shown to the participants, targeting those who were not literate. At each of the deliberative polls, the participants were randomly assigned to small groups of approximately 15 people each. In the groups, participants discussed in detail the pros and cons of each of the policy proposals. All discussions were held in the local language. Each group was moderated by a trained moderator while a research assistant took notes and managed the tape recording. Three such discussion sessions, each lasting approximately 2 hours, were held covering one of the three policy themes: (1) Re-settlement management, (2) land-use management and (3) managing population pressure. During the deliberation, key questions that could not be resolved in the discussion were documented. These constituted the contentious issues representing key information gaps and issues of concern for which participants sought more information. These issues were the basis for the findings discussed in this paper. Following the small group discussions, participants went into plenary sessions that included the entire sample of participants. The purpose of the plenary discussions was to resolve the information gaps and issues of concern that arose in the small group discussions. A cross-disciplinary panel of experts explained and clarified all the issues of concern.

Post deliberation opinion poll: After two days of small group and plenary deliberations, the participants were asked to respond to the post-deliberation survey. Individual interviews were conducted using the same questionnaire as used in the pre-deliberation survey.

\section{Data analysis}

The small group recordings were labelled and stored. They were then transcribed and translated into English by an experienced research assistant fluent in both languages. A content analysis approach was used, as described by Graneheim and Lundman [11] and applied by Nelson and colleagues [12]. All transcripts were entered into Atlas Ti, Version 5.2. A core team of authors: RWM (a public health specialist), LA (an Anthropologist), NT (a health services research specialist), GMB (a public health specialist) and JS (a health system researcher) read the transcripts to identify emerging unresolved questions and concerns from the small group discussions. The team then met and consolidated the emergent issues, following which they selected concerns and questions that represented barriers to uptake of climate risk related policies in the three policy domains. They then cleaned out repetitions and merged similar ones. Following the initial descriptive analysis, over-arching latent themes were then derived from the manifest themes [11].

\section{Validity}

Several methodological approaches were used to promote validity of the process. The inter-disciplinary team brought a variety of perspectives into the study. Follow-up questions and probes by the moderators were used to validate responses during the discussions. The moderators were guided by wellcrafted briefing documents that clarified key policy issues to the discussants to make them adequately informed. The moderators checked repeatedly with participants to ascertain understanding, meanings and concordance. Several experts were involved in the analysis to derive emergent issues of concern. The face-to-face rapport with the participants promoted trustworthiness.

Ethical considerations

Ethical clearance was obtained from the Makerere University School of Public Health Higher Degrees Research and Ethics Committee and approval from the Uganda National Council of Science and Technology (UNCST) [Study number SS 3532]. Permission to carry out the research was further sought from Bududa and Butalejja district administrations. 
Study objectives, benefits and risks were explained to participants. In addition, respondents had the opportunity to ask questions or clarification before providing written informed consent for the interview to proceed. All information obtained during the study was treated as confidential.

\section{Results}

In this section we describe the thematic structure of our analysis, showing the main themes and sub-themes regarding concerns, information barriers and misconceptions hampering the uptake of climate risk mitigation policies in Bududa and Butalejja Districts. Key questions for the analysis were: What drives communities to return to areas from where they have been resettled; Community concerns and misconceptions regarding land rights and land management, community concerns and misconceptions hindering uptake of family planning. The key emerging themes were resettlement in unfamiliar territory; uncertainty about land ownership; asking for Government assistance for practically everything. Regarding family planning, the key emerging theme was lack of safety guarantees for Family Planning users fueling feelings of helplessness in the event of a side effect thus hindering uptake of family planning. The details are presented and discussed below.

Background socio-demographic characteristics of respondents

Compared to other deliberative polls conducted globally, the sample recruitment for this poll was highly successful. Random sampling and selection produced 210 completed interviews in Bududa and 232 in Butalejja. In each district there were only 11 potential respondents who declined to complete the initial interviews, representing a response rate of $95 \%$. Of the 210 who completed the initial interviews in Bududa, 201 attended the deliberation workshop (95.7\%). Of the 232 who completed the initial interview in Butalejja, 217 attended $(93.4 \%)$. The overall participation rate was $94 \%$ as summarized in Table 1.

Table 1. Background socio-demographic characteristics of participants.

\begin{tabular}{|c|c|c|c|c|}
\hline & \multicolumn{2}{|c|}{ Bududa $(\mathrm{N}=201)$} & \multicolumn{2}{|c|}{ Butalejja $(\mathrm{N}=217)$} \\
\hline & $\mathbf{N}$ & $(\%)$ & $\mathbf{N}$ & $(\%)$ \\
\hline \multicolumn{5}{|l|}{ Gender } \\
\hline Male & 118 & 58.7 & 153 & 65.9 \\
\hline Female & 83 & 41.3 & 79 & 34.1 \\
\hline \multicolumn{5}{|l|}{ Age } \\
\hline $0-19$ & 2 & 1.0 & 9 & 4.2 \\
\hline $20-39$ & 81 & 40.3 & 99 & 45.6 \\
\hline $60+$ & 22 & 11.0 & 28 & 12.9 \\
\hline Mean Age (Years) & & 42.6 & & 40.1 \\
\hline \multicolumn{5}{|l|}{ Marital Status } \\
\hline Married & 181 & 90 & 199 & 91.7 \\
\hline Single & 10 & 5 & 13 & 6.0 \\
\hline Widowed & 7 & 3.5 & 3 & 1.4 \\
\hline Separate/Divorced & 3 & 1.5 & 2 & 0.9 \\
\hline None & 21 & 10.4 & 17 & 7.8 \\
\hline Primary & 116 & 57.7 & 124 & 57.1 \\
\hline O Level & 56 & 27.9 & 57 & 26.3 \\
\hline A Level & 2 & 1 & 8 & 3.7 \\
\hline Tertiary & 6 & 3.0 & 11 & 5.1 \\
\hline \multicolumn{5}{|l|}{ Occupation } \\
\hline Farmer & 174 & 86.5 & 186 & 85.7 \\
\hline Professional/technical/managerial & 4 & 2.0 & 12 & 5.6 \\
\hline Entrepreneur (business owner) & 7 & 3.5 & 8 & 3.7 \\
\hline Merchant & 2 & 1.0 & 1 & 0.5 \\
\hline Teacher & 4 & 2.0 & 2 & 0.9 \\
\hline Student & 4 & 2.0 & 4 & 1.8 \\
\hline Other & 6 & 3.0 & 4 & 1.8 \\
\hline \multicolumn{4}{|l|}{ Residence } & 6.9 \\
\hline
\end{tabular}

What drives communities to return to high-risk areas after they are resettled?

The key emergent theme motivating community members to return to high-risk areas after they are resettled is 'resettlement in unfamiliar and unproductive territory.

Participants raised concerns about what makes them resistant to resettlement from the high-risk zones. One concern was that they were resettled in an area with unfamiliar topography. They said that while they had grown up and were used to a mountainous area all their lives, they had instead been resettled in a district with a 'very flat terrain' characterized by grasslands, where they were not able to 'see 
the rest of the village'.

"I have been used to living in a mountainous area where I could easily see the villages and the homes below and above my household. I was resettled into a flat area where I could not see other homes except for my neighbours," (Male deliberator, Bududa)

Other participants cited the very fertile volcanic soils and the reliable rains in the mountains compared to the much less fertile soils with semi-arid weather where they were resettled. They noted that the land in the mountains is very productive and grows almost anything without need for fertilizers and cannot be comparable to the land in the district where they were resettled. The region from where they were resettled is also one of the few Arabica coffee growing areas in a country where coffee is the chief export and where this variety of coffee was the most valuable.

"This land is very fertile and grows anything with little effort. It's like you simply throw the seeds into the soil they will germinate and grow. You do not need any fertilizers. But the land where we were taken is barren!" (Female deliberator, Bududa)

Communities also cited social connections and political attachment to the land from where they were resettled, and the experience of losing their social networks after resettlement. Some of them cited ancestral attachment to the land where their grandparents were buried. Some political leaders said they experienced the loss of political power following resettlement, because some of their voters were resettled outside their own re-settlement zones. The loss of influence and potential voters after resettlement made them resentful to the resettlement. Others complained that they are inadequately consulted about where to be relocated and the compensation they would receive.

"All our ancestors were born, raised and buried here. We must also be buried here," (Female deliberator, Bududa).

"I was a Local Council chief but in my new settlement, I no longer have access to those who elected me," (Male deliberator, Bududa).

Community concerns and misconceptions regarding land rights and land management

Here, the key emergent theme was the uncertainty about land ownership with the key emerging theme being loss of control. Communities expressed several concerns regarding land rights and land management both in their original settlements and where they were resettled, as barriers to their acceptance of the resettlement program. Some discussants were concerned that the government was not clear on the ownership of the land where they are resettled. They said that while they owned the land where they previously stayed, they felt that the land where they were resettled was not theirs and they could be evicted anytime. Others said that it was not clear who owned the land that they left behind. Several discussants did not trust government to be vigilant in preventing other encroachers from occupying the land from which they were resettled. Some discussants went to the extent of perceiving the resettlement as 'a trick to give away their land'. They argued there is no reason for them to leave when other people will occupy their land anyway:

"Government is not clear on how the land we leave behind will be managed. With their carelessness, other people will take over our land for free; we have already witnessed this in some of the areas that we left." (Female deliberator, Bududa)

In Butalejja, there were prevalent misconceptions regarding trees and their role in mitigation of climate variability viz-a-viz their perceptions about ownership of forests. Some participants, for example, expressed the misconception that if they planted many trees, their land would be re-gazetted as a forest. Other participants expressed a misconception that trees were responsible for the intense rains that caused landslides and floods.

"Since major forests belong to government, won't my land be taken over as a national forest if I plant many trees?" (Male deliberator Butalejja)

Following the deliberation, community members were increasingly in support of policy options on resettlement, provided they were involved in planning the entire process. However, communities were also increasingly in support of measures for local management of risk in moderate risk zones, including measures that are not part of the current official policy. For example, some of the community members supported a clear rezoning exercise to re-demarcate high risk areas for no settlement but conditional upon resettling them within the same geographical region as where they resided. Other participants supported options that would allow careful management of risk in the moderate risk zones. For example, some participants proposed provision of support to families in the 'safer' areas to temporarily host people from the moderate risk zones at the peak of the rainy season, thus avoiding complete resettlement from those areas. Other participants supported a transition to semi-urban dwellings in the vicinity of their farmlands that would allow for controlled agriculture on the moderate risk slopes. The emergent theme was that it is possible to manage risk locally in moderate risk zones.

Extent to which communities feel they have agency to take charge of climate risk mitigation

A key latent theme emerging from the discussions on land use management to reduce disaster risk was the pervasive expectation by communities to be assisted by both local and central government in all areas of their need, expressed locally in the repetition of the phrase "'Tusaba Gavumenti etuyambe"' (translated into, "we want government to assist us"). For example, asked about what options they have to be able to diversify their livelihoods, discussants from the rice growing communities said that government should assist them to diversify their livelihoods because they lack viable livelihoods options. Asked about their capacity to prevent small rivers and water channels from getting clogged by desilting them, many discussants were resigned about the community's ability to maintain drains. They said that desilting of rivers to prevent floods requires heavy machinery which are located far away from them and inaccessible. 
Discussants requested external help. The same views were expressed regarding maintenance of local foot-bridges, enforcement of latrine construction, and participation in early warning against flooding - in all cases, they expected government to assist them. It was noted that some community members in Butalejja illegally extend the water channels to ungazetted rice gardens in the lower areas, hence draining the gazetted rice areas on higher ground and stifling their ability to flood sufficiently for rice growing. Discussants expressed helplessness in addressing this practice and asked for the government's intervention.

At the local government level, the community leaders complained about insufficient funding for coordination of disaster management. However, while the districts said they do not have adequate funds, the central government says that the budget process is bottom-up and begins with districts contributing to the Budget Framework Paper. The districts were adamant, arguing that their budget priorities are usually not honored. However, because of the deliberation, participants were able to identified some actions they thought they could take on within the resources they have, and without necessarily relying on external assistance. For example, there was increased post-deliberation support for communities taking more responsibility to manage the wetlands during the dry season. There was also increased support for rice dependent communities to diversify to nonflood dependent upland rice and other sources of livelihoods. Communities were also more in support of taking charge of last mile transmission of early warning information, provided they received the right information in a timely manner.

Community concerns and misconceptions hindering uptake of Family Planning

The emergent theme was the lack of safety guarantees for Family Planning users fueling feelings of helplessness in the event of a side effect thus hindering uptake of Family Planning. Another emergent theme was communities not linking family size to resource constraints. This is a subtle yet very significant factor.

Communities had various misconceptions and concerns regarding Family Planning including misconceptions about the side effects of Family Planning methods and uncertainty on where to seek help in case they developed side effects.

"We have heard that Family Planning causes many side effects including tampering with our internal body organs, giving birth to deformed children or not conceiving again?" (Male deliberator, Bududa)

"When they are mobilizing us to use Family Planning they are very aggressive; but they are not as aggressive when you develop side effects. Where for instance would I go if I have a side effect and who would help me? They will not work on me with the same vigor as when they want me to use Family Planning, " (Female deliberator, Butalejja)

A key emerging theme was anticipation of helplessness when faced with a side effect of Family Planning. Communities were concerned that the public health system seems to focus more on uptake, but they are not sure of continuity of services in the event of a serious side effect. There were some gender differences in the negative perceptions related to Family Planning. Males were more concerned about the effects of Family Planning on sexual performance and their future fecundability, while women were concerned about the low involvement of men in Family Planning. Male participants had the misconception that Family Planning reduces sexual performance. Other participants were concerned about the irreversibility of male Family Planning methods:

"We hear that Family Planning reduces sexual power. It may also fail to reverse when you decide to have children. Your wife may become completely infertile." (Male deliberator, Bududa)

"What happens to me if I marry another woman after undergoing vasectomy, and she wants children?" (Male deliberator, Butalejja)

On the other hand, women discussants were concerned that Family Planning methods were mostly for women and there was lack of regular alternatives for men. Women were also concerned about the behavior of men regarding Family Planning and how it can be controlled:

"Why are there no Family Planning methods for men? I am also concerned about the behavior of these men. Is there a way we can stop men from marrying more than one wife to reduce on population increase?" (Female Deliberator, Butalejja)

"Can government institute laws forcing men to go for Family Planning with their wives?” (Female Deliberator, Bududa)

An interesting trend in perceptions was observed in which people with large family sizes felt that they should be assisted with social grants and entitlements only on the basis of having large families to support. Some of them viewed having many children as a positive contribution to society that needs to be rewarded. Other participants viewed having many children as a strain that was not their fault and that they should be supported by government. Many men also failed to see the link between large families and shrinking resources, thinking that it was the land that was getting scarce other than recognizing the people increasing in numbers.

"I have 12 children; with all these children my land is getting smaller; why shouldn't government give people like me more land?" (Male deliberator, Butalejja)

"Our land is getting smaller and smaller; government should give us land" (Male deliberator, Bududa)

"No, it is not the land getting smaller; it is the population getting bigger; according to the Constitution of Uganda,

'all land belongs to the people."' (Expert panelist, Bududa deliberative poll)

The key emergent theme therefore was Family size being linked to feelings of entitlement to government support, without linking family size to resource constraints, and perhaps believing that land exists elsewhere as an abundant resource and that it was the duty of government to re-allocate it to those who have larger families.

Table 2 summarizes the key results and emergent themes. 
Table 2. Summary of the key results and emergent themes.

\begin{tabular}{|c|c|c|c|}
\hline Questions & Emerging subthemes & Emerging theme & Latent theme \\
\hline $\begin{array}{l}\text { What drives } \\
\text { communities to } \\
\text { return to areas from } \\
\text { where they have been } \\
\text { resettled? }\end{array}$ & $\begin{array}{l}\text { The topography is unfamiliar } \\
\text { The soils are infertile } \\
\text { Loss of social connections } \\
\text { Loss of cultural connections } \\
\text { Loss of voters and political power }\end{array}$ & $\begin{array}{l}\text { Resettlement in } \\
\text { unfamiliar territory }\end{array}$ & Loss of control \\
\hline $\begin{array}{l}\text { Community concerns } \\
\text { and misconceptions } \\
\text { regarding land rights } \\
\text { and land } \\
\text { management }\end{array}$ & $\begin{array}{l}\text { "Who owns the land that we are leaving behind?" } \\
\text { "Who owns the land that where we are resettled?" } \\
\text { "Government will be negligent and allow other encroachers to occupy the land we leave behind" } \\
\text { "If I plant trees, won't my land be gazetted as a government forest?" } \\
\text { "We can stay with relatives in safer areas at the time of highest risk" } \\
\text { "We can practice controlled farming in the high-risk zones but stay in semi-urban dwellings" } \\
\text { Government should assist us to diversify livelihoods }\end{array}$ & $\begin{array}{l}\text { Uncertainty about } \\
\text { land ownership } \\
\text { It is possible to } \\
\text { manage risk locally }\end{array}$ & Loss of control \\
\hline $\begin{array}{l}\text { Extent to which } \\
\text { communities feel } \\
\text { they have agency to } \\
\text { take charge of risk } \\
\text { mitigation }\end{array}$ & $\begin{array}{l}\text { The equipment needed for regular desilting of water channels is beyond our capability; } \\
\text { government should assist } \\
\text { Government should maintain the local foot bridges } \\
\text { Government should assist us in constructing suitable latrines for the high-water table } \\
\text { Government should operate the local flood early warning } \\
\text { Government should deal with the people who illegally extend the water channels } \\
\text { We do not have adequate budget to operationalize the District Disaster Management } \\
\text { Committees; government should assist }\end{array}$ & $\begin{array}{l}\text { Government } \\
\text { should assist us in } \\
\text { everything }\end{array}$ & $\begin{array}{l}\text { Low agency for } \\
\text { local solutions }\end{array}$ \\
\hline $\begin{array}{l}\text { Community concerns } \\
\text { and misconceptions } \\
\text { hindering uptake of } \\
\text { family planning }\end{array}$ & $\begin{array}{l}\text { Family planning causes serious side effects } \\
\text { "Where do we go when we have side effects (of family planning) and shall we get help?" } \\
\text { Men are concerned about the effects of Family Planning on sexual performance } \\
\text { Women are concerned that health workers do not engage men in in Family Planning as } \\
\text { much as they do to them } \\
\text { Because I have a large family size, government should provide me with assistance } \\
\text { Our land is getting smaller and smaller; government should give us more land }\end{array}$ & $\begin{array}{l}\text { Feelings of } \\
\text { helplessness in the } \\
\text { event of a side } \\
\text { effect } \\
\text { Family size linked } \\
\text { to feelings of } \\
\text { entitlement }\end{array}$ & $\begin{array}{l}\text { No safety } \\
\text { guarantees for } \\
\text { Family Planning } \\
\text { users } \\
\text { Communities do } \\
\text { not link family } \\
\text { size to resource } \\
\text { constraints } \\
\end{array}$ \\
\hline
\end{tabular}

\section{Discussion}

The return of communities to high-risk settlements from where they were previously resettled is driven by concerns about the type of land where they are resettled, their cultural attachment to the land, as well as the fear of losing long cultivated critical socio-political relationship networks. Studies show that improperly managed involuntary resettlement can result into adverse impacts on affected populations [13]. Negative outcomes of involuntary resettlement are reported regarding employment, sustainable livelihoods, social and gender roles and lifestyle issues [13, 14]. The fear of losing cultural attachment to land, along with the loss of social connectedness, has been expressed in other studies that show loss of family bonds and critical social networks when people are displaced [15]. Resettled communities suddenly feel as if they have lost important physical and social capital that they have built over several years. The policy implication of this finding is that communities in high-risk zones ought to be consulted closely when planning resettlement. They should be involved in the planning of the new settlement. They should also be resettled in geographical areas that have familiar terrain. Mechanisms to preserve their cultural values and linkages ought to be discussed as part of the resettlement plans [16].

Regarding land rights and management, communities had concerns about what resettlement meant for ownership of their land. A rights-based approach to management of land resources was highlighted by United Nations Population Fund (UNFPA) and the International Institute for Environment and
Development, especially for people that are forcefully evicted by natural disasters [17]. This approach should provide for an institutional framework to protect the rights of displaced persons [17]. In the article entitled 'The Law is to Blame: The Vulnerable Status of Common Property Rights in Sub-Saharan Africa', Wily Liz Alden [18] notes that it is not new that vulnerable people lose land in Africa, but that the biggest enabler is the weak legal status of communal land systems that allows government to take undue influence on citizens' land [18]. There were also prevalent misconceptions about ownership of forests as an impediment to community driven re-forestation. Fay and Michon [19] note that forest land delineation and gazetting has sometimes been a restriction on small-holder land access [19]. Other authors also note the sensitive nature of forests and land access in low- and middleincome countries [20-22]. These characterizations of forests as owned by government are not new and have been noted in multiple other reviews to be an offshoot of archaic colonial laws [20,23]. After deliberation, community members' support of policy options on better land use and local management of risk increased. They were open to rezoning of high-risk areas, as well as options that allowed for controlled agriculture in moderate risk zones [16].

Similar to the earlier discussion on resettlement, the latent theme underlying the community's perceptions about land use is fear of loss of control. Communities want to be in control of their land resources including clear ownership of land where they are resettled, involvement in clear re-zoning of high-risk zones, and an opportunity to participate in measures to manage risk locally in moderate risk zones. 
The study findings also show that without sensitization and an opportunity to debate the issues, communities have low agency to identify risk reduction measures that they can adopt without the need for external help. The highly prevalent expectations that it is government's role to provide all local solutions is currently a deeply entrenched culture, engulfing entire communities across the country, and has cultivated an excessive expectancy among the communities for government to swing in and bail out its citizens who are in perpetual need of assistance. This has inadvertently led to a culture of helplessness and has literally eroded the agency and capacity of communities to manage risk locally without the need to rely on external assistance.

Before communities in the study area were engaged in the deliberation on potential policy options, they seemed to view themselves as incapable of taking local actions to mitigate disaster risks. The repetition of the phrase 'we want government to assist us' for almost all suggested interventions might actually mean 'we feel incapable (of taking local initiative)' and is indicative of a resilience gap. According to the $\mathrm{CDC}$ and other authoritative agencies on disaster risk reduction, all disasters are local and initial response capacity should be the priority for risk mitigation programs [24]. Risk reduction and response activities should therefore be premised on initially mobilizing the local agency of affected communities to take charge of mitigation and response activities as a prerequisite for building resilient communities [25]. Post-deliberation, the expectation of perpetual assistance from government appeared to change when communities were empowered to deliberate and weigh the available options. There is an increasing dearth of literature on deliberative democracy and how it can help shape informed policy buy-ins from communities. James Fishkin et al. [8] proposes an approach to community involvement based on five principles: access to information to foster informed decision making, substantive balance between perspectives, diversity of representation, conscientiousness (in all cases weighing the benefits and demerits) and equal consideration (arguments are considered on their merits, not characteristics of the contributor) [8]. Mechanisms for a more deliberative approach to introduce climate risk mitigation policies should therefore be explored, to foster closer community involvement and informed participation.

The misconceptions and concerns regarding Family Planning were a key driver of low uptake, a key contributing factor to high population pressure. The results from the Deliberative Poll in Bududa and Butalejja are consistent with findings from other studies in sub-Saharan Africa that bring to light the sociocultural and health system factors that drive households to seek larger families, namely: socio-cultural pressures to have larger families, concerns about Family Planning methods especially their side effects and reversibility, Family Planning being viewed as an issue for women, and inadequate explanations given by health care workers [26-28].

The negative attitudes and behavior of men to Family Planning observed in this study have been documented in various other studies [29-31]. In general, two latent themes emerged from the community concerns regarding Family Planning, the first being the feelings of 'no safety guarantees for Family Planning', and the second being 'communities not linking family size to scarcity of resources and land', hence leading to 'feelings of entitlement to support because of having a large family'. This is a notable finding from this community not commonly described in other studies. These perceptions represent a substantial gap in these communities' ability to respond to continuing population pressure and should be addressed directly by tailored Family Planning messages, including sensitization and involvement of men in deliberations on Family Planning at the household level in order to have a more resilient community.

\section{Methodological Considerations}

The credibility of this study is that we are interpreting the qualitative findings arising from small groups who were selected from the community using a stratified random sampling method. It is rare for qualitative work to be done in situations where the number of group discussions together is enough to add up to a credible representative sample of the population. The limitation, however, was that participants were heterogeneously composed. Therefore, it was not possible to conduct analysis by the 3 zones from which participants were selected. Nevertheless, these small group discussions generated rich and diverse discussions about climate risk mitigation policies in Bududa and Butalejja Districts.

\section{Implications for deliberative practice}

Beyond what may be obtained through other research techniques, what is distinctive or specifically valuable about a deliberative polling approach is that it fosters public consultation. Stakeholders or policy experts who speak on behalf of the people usually turn out to have different views from the people they represent [32]. Self-selected forums are unrepresentative and usually dominated by those especially motivated to turn out as they anticipate the distribution of benefits rather than deliberation about the general good of the community [33]. Focus groups, though useful for uncovering community insights, are not effective for representative opinion gathering because they are too small to be statistically meaningful and involve purposive selection. Conventional polls, while potentially representative when done well, largely offer the public's impression of 'sound-bites' and headlines, denying the public the opportunity to carefully think through the issues. Moreover, opinion poll participants are non-randomly selected making it hard to generalize findings. Deliberative polling fosters thoughtful weighing of the arguments for and against policy alternatives by representative microcosms of the public [34]. The basic idea of the DP is that it uses a random and representative sample of participants to deliberate under good conditions and think through and consider the issues and the results represent what the public would think were it to engage with the issues under similarly good conditions [35, 32]. This strategy makes deliberative democracy a practical and implementable theory, at least for the policy issues selected. The numbers who participate may be smaller than in mass participatory institutions, but the conclusions offered can represent the public's considered judgments. 
Deliberative polling contributes to climate risk mitigation/ resilience as an innovative way of consulting communities. It provides a roadmap to the policies the public may find favorable, those the public may reject and why. Deliberative Polling contributes to our understanding of things policymakers/development agencies do wrong when they lay out prescriptive, one-stop solutions to intricate, socioenvironmental-demographic issues faced by the community. This consultation helps to draw insights and conclusions on what keeps communities in a perpetual state of vulnerability and design interventions that address these vulnerabilities. Resilience can only be built if these latent variables that drive risky behavior are addressed.

\section{Conclusions}

This study explores perceptions and attitudes that prevent communities from adopting well-intentioned policies regarding sustainable settlement, land use management and family planning, particularly those at high risk. It clarifies that communities have concerns and information gaps that prevent them from embracing climate risk mitigation policies Not only were communities distrustful of how the land from which they are evacuated would be managed, but they also resented being resettled in unfamiliar places. There is a pervasive expectation by communities to be assisted by government in all areas of their livelihood needs. Key barriers to Family Planning included lack of safety guarantees, helplessness in the event of a side effect, failure by communities to link family size to resource constraints, and feelings of entitlement to assistance among people with large families. These misconceptions are fueled by a large information asymmetry between the community members and the policy makers and they lead to sub-optimal compliance to climate risk related policies and persistence of behaviours that keep communities highly vulnerable. It is through a deliberative process that these issues can be brought to light and addressed by policy makers.

\section{Recommendations}

To increase the adoption of risk mitigation policies, there is need to address the prevalent information asymmetries and misconceptions in the communities through targeted sensitization in the following areas: We recommend that sensitization of communities on resettlement management should focus on addressing prevailing concerns about resettlement in unfamiliar territory to minimize loss of social connections, and concerns about land ownership among others; We also recommend that sensitization on proper land use management should focus on how to enhance the capacity of local communities to take on local measures for risk mitigation rather than waiting upon government to provide all the solutions. Regarding the information asymmetries on Family Planning, we recommend that health programmers conduct urgent, regular and targeted sensitization to address the persistent questions and misconceptions, especially regarding side effects of FP methods and where people can get help when faced with such side effects.

We also recommend that to increase uptake and successful implementation of climate risk mitigation policies, there is a need to increase community engagement in the policy formulation process. When communities are adequately consulted, and their concerns addressed, their support for policy options to reduce climate-related disaster risk increases.

\section{List of Abbreviations}

RAN: ResilientAfrica Network; DP: Deliberative Polling $®$; UNCST: Uganda National Council of Science and Technology; CAO: Chief Administrative Officer; UNFPA: United Nations Population Fund

\section{Declarations}

\section{Ethical Approval and Consent to Participate}

Ethical clearance was obtained from the Makerere University School of Public Health Higher Degrees and Ethics Committee and approval from the Uganda National Council of Science and Technology (UNCST) [Study number SS 3532]. Permission to carry out the research was further sought from Bududa and Butalejja district administrations. Study objectives, benefits and risks were explained to participants. In addition, respondents had the opportunity to ask questions or clarification before providing written informed consent for the interview to proceed. All information obtained during the study was treated as confidential.

\section{Availability of Supporting Data}

All data generated or analyzed during this study are available upon request to the authors.

\section{Competing Interests}

The authors declare that they have no competing interests.

\section{Funding Statement}

Funding for this research was made possible by the generous support of the American people through the United States Agency for International Development (USAID). The views and opinions expressed in this paper are those of the authors and do not necessarily reflect the views of USAID or the United States Government.

\section{Authors' Contribution}

RWM, NT, GMB, JS, HA, AS, KG, SN, LA, and JF contributed to the study concept and design, data collection and supervision, analysis and write-up of the manuscript. RWM drafted the initial manuscript. WB, JF contributed to the study conceptualization and design and manuscript writing. LA, GMB and CM conducted a comprehensive review and editing of the manuscript. All authors read and approved the final manuscript. 


\section{Appendix}

Table A1. The 36 policy options on Resettlement Management, Land Use Management and Population Pressure.
1. Re-zone high risk and moderate risk areas for no settlement
2. Compensate people who have to move from a high-risk area
3. Resettle with a host family in a low risk area when there is a disaster
4. Give support to the host families for helping those who move
5. Strengthen the local disaster management committees.
6. Raise funds to support the work of the local disaster management committees
7. Give trainings to the local disaster management committees
8. Build peri-urban centers where people can resettle
9. Make sure new peri-urban centers are nearby so people can farm.
10. Build early warning systems for floods and landslides
11. Early warning systems should use sirens
12. Early Warning systems should use text messages
13. Ensure that the early warning system works with the local disaster committees
14. Plant trees to protect the river banks
15. Dig river channels with help of local government
16. Communities should manage the wetlands during the dry season.
17. Communities should create more rice schemes, but not in the wetlands
18. Communities should maintain water channels during the wet season
19. Communities should be sensitized on the benefits of planting a variety of crops
20. Communities should be responsible for desilting riverbeds.
21. Government should assist communities in desilting riverbeds
22. Communities should build sanitation drains for the reduction of malaria
23. Government should assist in drilling for water where possible
24. Communities should be provided with resources for access to clean safe water
25 . The govt should build roads in remote areas to allow farmers easier access to markets
26. The govt should build more bridges
27. The government should raise narrow bridges
28. New buildings should have high floors in low land areas
29. Communities should build ladders in the highlands where there are not roads.
30. The govt should build one-class schools for elementary education in remote areas
31. The community should encourage girls to go to school as well as boys
32. The community should create more technical schools for both girls and boys
33. The govt should enforce minimum age requirements for marriage of 18 years
34. Families should consider their resources in planning the size of their families.
35. Offer more education about family planning
36 . Health centre IIs should be established in small villages

\section{References}

[1] IPCC. (2012). Intergovernmental Panel On Climate Change (Ipcc) Managing The Risks Of Extreme Events And Disasters To Advance Climate Change Adaptation - Summary for policymakers. Managing the risks of extreme events and disasters to advance climate change adaptation. A Special Report of Working Groups I and II of the Intergovernmental Panel on Climate Change. https://doi.org/10.1017/CBO9781139177245.

[2] IPCC. (2014). Intergovernmental Panel on Climate Change (IPCC) AR5 synthesis report: Climate change 2014. Climate Change 2014: Synthesis Report. Contribution of Working Groups I, II and III to the Fifth Assessment Report of the Intergovernmental Panel on Climate Change. https://doi.org/10.1017/CBO9781107415324.

[3] RAN. (2015). Resilient Africa Network (RAN). The State of African Resilience; Understanding Dimensions of Vulnerability and Adaptation. Retrieved from http://pdf.usaid.gov/pdf_docs/PBAAC215.pdf last accessed September 252017.

[4] National Planning Authority. (2015). Second National
Development Plan (NDPII) Uganda 2015/16-2019/20. National Planning Authority Uganda. https://doi.org/10.1111/j.1475-6773.2006.00624.x.

[5] Pomeroy, D. Tushabe, H. and Loh, J. (2017). The State of Uganda's Biodiversity 2017. Kampala, Uganda. https://doi.org/ISBN: 978-9970-9690-0-5.

[6] World Bank. (2019). The World Bank In Uganda. Retrieved May 2, 2019, from https://www.worldbank.org/en/country/uganda/overview.

[7] UBOS (2014). National Population and Housing Census, Main Report, Kampala, Uganda. ubos.org/wpcontent/uploads/publications/03_20182014_National_Census_ Main_Report.pdf.

[8] Fishkin, J. S., Mayega, R. W., Atuyambe, L., Tumuhamye, N., Ssentongo, J., Siu, A., \& Bazeyo, W. (2017). Applying deliberative democracy in Africa: Uganda's first deliberative polls. Daedalus. https://doi.org/10.1162/DAED_a_00453.

[9] Atuyambe, L. M., Ediau, M., Orach, C. G., Musenero, M., \& Bazeyo, W. (2011). Land slide disaster in eastern Uganda: Rapid assessment of water, sanitation and hygiene situation in Bulucheke camp, Bududa district. Environmental Health: A Global Access Science Source. https://doi.org/10.1186/1476-069X-10-38. 
[10] UDHS. (2016). Uganda Demographic Health Survey 2016. Uganda Demographic and Health Survey 2016.

[11] Graneheim, U. H., \& Lundman, B. (2004). Qualitative content analysis in nursing research: Concepts, procedures and measures to achieve trustworthiness. Nurse Education Today. https://doi.org/10.1016/j.nedt.2003.10.001

[12] Nelson, B. B., Chung, P. J., DuPlessis, H. M., Flores, L., Ryan, G. W., \& Kataoka, S. H. (2011). Strengthening families of children with developmental concerns: Parent perceptions of developmental screening and services in head start. Ethnicity and Disease.

[13] Badri, S. A., Asgary, A., Eftekhari, A. R., \& Levy, J. (2006). Post-disaster resettlement, development and change: A case study of the 1990 Manjil earthquake in Iran. Disasters. https://doi.org/10.1111/j.0361-3666.2006.00332.x.

[14] Cernea Michael M., M. C. (2000). The effects of resettlement on access to common property resources - Risks and reconstruction: experiences of resettlers and refugees. Washington. Retrieved from ocuments.worldbank.org/curated/en/947311468739277702/pd f/multi-page.pdf.

[15] Roizblatt, A., \& Pilowsky, D. (1996). Forced migration and resettlement: Its impact on families and individuals. Contemporary Family Therapy. https://doi.org/10.1007/BF02195714.

[16] Neema, S., Mongo Bua, G., Tuhebwe, D., Ssentongo, J., Tumuhamye, N., Mayega, R. W.,... Bazeyo, W. (2018). Community Perspective on Policy Options for Resettlement Management: A Case Study of Risk Reduction in Bududa, Eastern Uganda. PLoS Currents. https://doi.org/10.1371/currents.dis.49e8e547de25ca1c1f9edb bfc8b9efa5.

[17] Guzmán, J. M., G; McGranahan, G; Schensul, D; Tacoli, C. (2009). Population Dynamics and Climate Change (2009th ed.). New York and London: UNFPA and IIED. Retrieved from https://www.iied.org/population-dynamics-climatechange-book

[18] Wily, L. A. (2011). "The Law is to Blame": The Vulnerable Status of Common Property Rights in Sub-Saharan Africa. Development and Change. https://doi.org/10.1111/j.14677660.2011.01712.x.

[19] Fay, C., \& Michon, G. (2005). Redressing forestry hegemony when a forestry regulatory framework is best replaced by an Agrarian One. Forests Trees and Livelihoods. https://doi.org/10.1080/14728028.2005.9752520.

[20] Lee Peluso, N. (2011). Whose Woods are These? CounterMapping Forest Territories in Kalimantan, Indonesia. Antipode.

[21] Lynch, O. J., \& Talbott, K. (1995). Balancing acts: community-based forest management and national law in Asia and the Pacific. Lynch, Owen J Talbott, Kirk.

[22] Peluso, N. L. (1992). Rich Forests, Poor People Resource Control and Resistance in Java. University of California Press. Retrieved from https://www.ucpress.edu/book/9780520089310/rich-forestspoor-people.
[23] Vandergeest, P. (1996). Mapping nature: Territorialization of forest rights in Thailand. Society and Natural Resources. https://doi.org/10.1080/08941929609380962.

[24] CDC. (2017). CDC Crisis and Emergency Risk Communication (CERC). Retrieved May 10, 2019, from https://emergency.cdc.gov/cerc/cerccorner/article_102116.asp.

[25] Becker, C. (2009). Disaster Recovery: A Local Government Responsibility. (cover story). Public Management 00333611.

[26] Capurchande, R., Coene, G., Roelens, K., \& Meulemans, H. (2017). "If I have only two children and they die. who will take care of me?" -a qualitative study exploring knowledge, attitudes and practices about family planning among Mozambican female and male adults. BMC Women's Health. https://doi.org/10.1186/s12905-017-0419-6.

[27] Ntambue, A. M., Tshiala, R. N., Malonga, F. K., Ilunga, T. M., Kamonayi, J. M., Kazadi, S. T., ... Donnen, P. (2017). Use of modern contraceptive methods in the Democratic Republic of the Congo: prevalence and barriers in the health zone of Dibindi, Mbuji-Mayi. Utilisation Des Methodes Contraceptives Modernes En Republique Democratique Du Congo: Prevalence et Barrieres Dans La Zone de Sante de Dibindi a Mbuji-Mayi.

[28] Tibaijuka, L., Odongo, R., Welikhe, E., Mukisa, W., Kugonza, L., Busingye, I., ... Bajunirwe, F. (2017). Factors influencing use of long-acting versus short-acting contraceptive methods among reproductive-age women in a resource-limited setting. BMC Women's Health. https://doi.org/10.1186/s12905-0170382-2.

[29] Akaba, G., Ketare, N., \& Tile, W. (2016). A community-based, mixed-methods study of the attitudes and behaviors of men regarding modern family planning in Nigeria. International Journal of Gynecology and Obstetrics. https://doi.org/10.1016/j.ijgo.2016.04.009.

[30] Apanga, P. A., \& Adam, M. A. (2015). Factors influencing the uptake of family planning services in the Talensi district, Ghana. Pan African Medical Journal https://doi.org/10.11604/pamj.2015.20.10.5301.

[31] Genet, E., Abeje, G., \& Ejigu, T. (2015). Determinants of unmet need for family planning among currently married women in Dangila town administration, Awi Zone, Amhara regional state; A cross sectional study. Reproductive Health. https://doi.org/10.1186/s12978-015-0038-3.

[32] Fishkin, J. S., \& Luskin, R. C. (2005). Experimenting with a Democratic Ideal: Deliberative Polling and Public Opinion. Acta Politica. https://doi.org/10.1057/palgrave.ap.5500121.

[33] Irvin, R. A., \& Stansbury, J. (2004). Citizen Participation in Decision Making: Is It Worth the effort? Public Administration Review. https://doi.org/10.1111/j.15406210.2004.00346.x.

[34] Fishkin, J. S. (2011). When the people speak: Deliberative democracy and public consultation. Oxford University Press.

[35] Fishkin, J. S. (1997). The Voice of the People: Public Opinion and Democracy By Fishkin James S. Yale university press. 